\title{
Evaluation of Anaemia in Children in Adivasi Population of Jharkhand
}

\author{
Dr. Chanchal Ashok ${ }^{1}$, Dr. Deepankar ${ }^{2 *}$, Dr. Vidyapati ${ }^{3}$, Dr. USP Keshri ${ }^{4}$
}

${ }^{1}$ Medical Officer, General Hospital, Brambe, Ranchi, Jharkhand

${ }^{2}$ Eye Specialist, Sadar Hospital, Ranchi, Jharkhand

${ }^{3}$ Professor of Medicine, RIMS, Ranchi, Jharkhand

${ }^{4}$ Professor of Pharmacology, RIMS, Ranchi, Jharkhand

DOI: $10.36347 / \mathrm{sajb} .2020 . \mathrm{v08i10.005}$

| Received: 06.10.2020 | Accepted: 20.10.2020 | Published: 23.10.2020

*Corresponding author: Dr. Deepankar

Abstract

Original Research Article

Background: In developing countries, anaemia is a major global health problem. India is among the countries with high prevalence of anemia. India's Adivasi scheduled tribe population are socially and economically vulnerable thus having higher incidence of anemia. Early detection and treatment of anaemia in young children play a major role in promoting the mental and physical growth and development. Material and Methods: This is a prospective study which included 100 children below 14 years of age. Blood samples were collected for haematological investigations. Results: Out of the total 100 cases, $55 \%$ were girls and $45 \%$ were boys. The most common type of anemia seen was microcytic hypochromic followed by normocytic normochromic anaemia. Conclusion: Anaemia is a common problem in adivasi children. Most anaemia in children is diagnosed with the blood tests. Its early diagnosis and treatment may help to reduce the rate of complications and thus improve the quality of life.

Keywords: Anaemia, children, adivasi, jharkhand, microcytic, normocytic.

Copyright $(\mathcal{C} 2020$ The Author(s): This is an open-access article distributed under the terms of the Creative Commons Attribution 4.0 International License (CC BY-NC 4.0) which permits unrestricted use, distribution, and reproduction in any medium for non-commercial use provided the original author and source are credited.

\section{INTRODUCTION}

Constitution of India under Article 366 (25) defines scheduled tribes as: "such tribes or tribal communities or parts of or groups within such tribes or tribal communities as are deemed under Article 342 to be Scheduled Tribes for the purposes of this constitution"[1]. Scheduled tribes in India comprise about $8.6 \%$ of the total population as per the 2011 Census [2]. These tribal people are commonly called "Adivasis" literally meaning original inhabitants, a term for diverse ethnic and tribal groups considered as India's indigenous population. In total, there are 573 communities that are recognized as scheduled tribes [3]. All tribes predominantly reside in the rural areas (93.9\%) [4]. Adivasis constitute one fourth of the population being counted to the poorest wealth decile and they are the least educationally developed [5]. They are found to live on very low incomes, most of them working as day labourers or with minor landholdings [6]. Only a few tribal children receive qualified medical treatment which is mainly due to physical remoteness to health facilities and also due to disbelief in conventional medicine providers [7]. Under-five-mortality rates are higher in Adivasis by $25 \%$ as compared to non-Adivasi children as they are socially and economically vulnarable[5].
Anaemia is a major health problem worldwide especially in paediatric age group and females in reproductive age group [8]. Anaemia is defined as a reduction in haemoglobin concentration below the level, which is expected for healthy persons of same age and sex and in the same environment. Iron deficiency is the most common cause of nutritional anaemia worldwide followed by folic acid and vitamin B12 deficiency anaemia [9]. The various causes of anaemia are low socio economic status, poor dietary habits, illiteracy, and poverty, loss of appetite and poor health status of mothers during pregnancy [8]. Fetal development is greatly influenced by maternal nutrition and therefore maternal iron deficiency during pregnancy is associated with fetal growth retardation, intra uterine growth retardation, inadequate weight gain, low birth weight and poor mental growth and development. On the basis of size of RBC which in turn is measured by the mean corpuscular volume (MCV), anaemia is classified morphologically into microcytic $(\mathrm{MCV}<80 \quad \mathrm{fl})$, normocytic (MCV $80-100 \mathrm{fl}$ ) or macrocytic (MCV> 100fl)[10]. According to haemoglobin value, anemia is divided as per WHO criteria into mild $(9-11 \mathrm{gm} / \mathrm{dl})$, moderate $(7-9 \mathrm{gm} / \mathrm{dl})$ and severe(less than $7 \mathrm{gm} / \mathrm{dl})$. 


\section{MATERIAL AND METHODS}

This is a prospective study done at General Hospital, Brambe, Ranchi, and Jharkhand. The aim of the study is to evaluate anaemia in children on the basis of morphological pattern. This is an observational study in which 100 cases were included who had Hemoglobin $11 \mathrm{~g} / \mathrm{dl}$ or less. Under aseptic precautions, venous blood was collected in a vacutainer containing EDTA. Haemoglobin ( $\mathrm{Hb})$ estimation, hematocrit (PCV), mean corpuscular volume (MCV), mean corpuscular haemoglobin $(\mathrm{MCH})$, mean corpuscular haemoglobin concentration (MCHC) values were obtained by using Sysmex five part differential automated cell counter. Peripheral blood smear was done for every patient.

\section{RESULTS}

A total of 100 cases were included in our study, out of which $55 \%$ were girls and $45 \%$ were boys (Table
1). The age varied from 6 months to 14 years. Majority of the patients were in the age group of 2-6 years (43\%) followed by the age 11 to 14 years which constituted $23 \%$ of the cases. According to haemoglobin value, majority of the cases $(47 \%)$ had moderate anaemia i.e. $\mathrm{Hb} 7-9 \mathrm{~g} / \mathrm{dl}$ followed by mild anaemia in $41 \%$ cases $(\mathrm{Hb}$ $9-11 \mathrm{~g} / \mathrm{dl})$ whereas severe anaemia was found only in $12 \%$ cases i.e. $\mathrm{Hb}$ less than $7 \mathrm{~g} / \mathrm{dl}$ (Table 2). The most common type of anaemia based on MCV was found to be microcytic hypochromic anaemia (40\%), followed by normocytic normochromic anaemia in $37 \%$ and macrocytic anaemia in $18 \%$ cases. Only $5 \%$ cases had dimorphic anaemia. Among the girls, microcytic hypochromic anaemia was most common followed by normocytic normochromic anaemia whereas Normocytic normochromic was the most common type of anaemia among boys followed by microcytic hypochromic anaemia (Table 3,4$)$.

Table-1: Demography

\begin{tabular}{|c|c|c|c|}
\hline \multirow{4}{*}{ GENDER } & & No. OF CASES & PERCENTAGE (\%) \\
\cline { 2 - 4 } & MALES & 45 & 45 \\
\cline { 2 - 4 } & FEMALES & 55 & 55 \\
\hline \multirow{4}{*}{ AGE(In Years) } & $\leq 1$ & 14 & 14 \\
\cline { 2 - 4 } & $2-6$ & 43 & 43 \\
\cline { 2 - 4 } & $7-10$ & 20 & 20 \\
\cline { 2 - 4 } & $11-14$ & 23 & 23 \\
\cline { 2 - 4 } & TOTAL & 100 & 100 \\
\hline
\end{tabular}

Table-2: Anaemia severity

\begin{tabular}{|c|c|c|}
\hline SEVERITY & No. OF CASES & PERCENTAGE (\%) \\
\hline MILD & 41 & 41 \\
\hline MODERATE & 47 & 47 \\
\hline SEVERE & 12 & 12 \\
\hline TOTAL & 100 & 100 \\
\hline
\end{tabular}

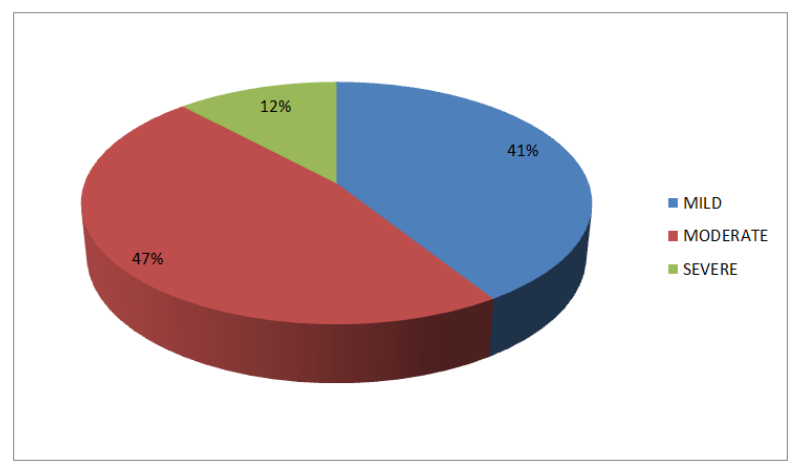

Fig-1: Severity of Anaemia

Table-3: Morphological classification of anaemia

\begin{tabular}{|c|c|c|c|}
\hline TYPE OF ANAEMIA & FEMALES & MALES & TOTAL \\
\hline $\begin{array}{c}\text { Microcytic Hypochromic } \\
\text { (MCV <80 fl) }\end{array}$ & 28 & 12 & 40 \\
\hline $\begin{array}{c}\text { Normocytic Normochromic } \\
\text { (MCV 80 - 100fl) }\end{array}$ & 16 & 21 & 37 \\
\hline $\begin{array}{c}\text { Macrocytic } \\
\text { (MCV> 100fl) }\end{array}$ & 7 & 11 & 18 \\
\hline Dimorphic & 4 & 1 & 5 \\
\hline TOTAL & 55 & 45 & 100 \\
\hline
\end{tabular}




\section{DISCUSSION}

In our study, anaemia was commonly observed in female patients (55\%) as compared to male. Our results were in concordance with the study done by Kapur et al. and Gandhi S et al. [11, 12]. In the studies done by Rathna et al. and Stiller et al. males were more common as compared to females $[13,14]$. In our study, majority of the patients were in the age group of 2-6 years which was similar to the study done by Stiller et al. on santhali(adivasi) children and another Indian study done by Prakash et al. [14,9]. In our study, majority of the cases $(47 \%)$ showed moderate anaemia followed by mild and severe aneamia in $41 \%$ and $12 \%$ respectively. These findings were in concordance to the studies done by Rathna et al. Jain et al. and Stiller et al. [13, 15, 14]. Stiller et al. did their study on Santhali (tribe) children of West Bengal. Jharkhand being adjacent state to West Bengal, the demographic pattern, composition of tribal population and their manner of living are almost similar. The most common type of anaemia in our study was microcytic hypochromic $(40 \%)$. The study done by Prakash et al. yield similar results. In females, microcytic hypochromic anaemia was most common followed by normocytic normochromic anaemia whereas Normocytic normochromic was the most common type of anaemia among boys. Our findings were similar to the study done by Rathna et al. [13].

\section{CONCLUSION}

Anaemia is a major health problem especially in individuals who are socially and economically vulnerable. It leads to impairment and delay the growth and development in young children. To build trust and remove disbelief between medical expert and Adivasis for bringing sustainable change, preventive and medical action have to be taken in cultural and sensible way. Early diagnosis and treatment of anemia may help to reduce the rate of complications and thus improve the quality of life.

\section{REFERENCES}

1. NCSC. Chapter II: Special Constitutional Provisions for Protection and Development of the Scheduled Castes and the Scheduled Tribes. National Commission for Scheduled Castes (NCSC), Government of India; New Delhi, India: 8-17.

2. Ministry of Home Affairs, Government of India Scheduled Castes and Scheduled Tribes.
3. Tribal people of India, Scheduled castes and scheduled tribes [(accessed on 31 December 2019)]; In India, Minorities, castes and regions: Facts and Details. 2015.

4. Office of the Registrar General and Census Commissioner, India, West Bengal. Data Highlights: The Scheduled Tribes, Census of India. RGCCI; New Delhi, India: 2001.

5. Das MB. Metha S.K. Issue Brief, Poverty and Social Exclusion in India: Adivasis. World Bank Group; Washington DC, USA: 2012.

6. Barman K. Central India Journal of Historical and Archaeological Research. Volume III. Vidya Career Research Foundation; Panna, India: 2014. Socio-Economic Profile of Tribal Populations in Birbhum District of West Bengal; 187-192.

7. Das MB, Hall G, Kapoor S, Nikitin D. India Country Brief No. 4. World Bank Group; Washington, DC, USA: 2011. Indigenous Peoples, India's Adivasis.

8. Campbell JM, Earl VD, Bertel B, Sameeth FA. A hematological survey of preschool children of the United Arab Emirates. Saudi Med J. 2003; 24(6): 609-13.

9. Prakash A, Kumar A, Awasthi S, Dutta S, Mittal A. Clinicopathological Pattern of Anemia in Children in Age Group Upto 18 years. Int J Med Res Prof. 2018 Jan; 4(1):262-5.

10. Janus J, Moerschel SK. Evaluation of Anemia in Children. Am FAM Physician. 2010 Jun; 81(12): 1462-71.

11. Kapur D, Aggarwal KN. Iron status of children aged 9-36 months in an urban slum ICDS Project in Delhi. Indian Ped. 2002; 39: 136-44.

12. Gandhi S, Khajuria A. Evaluation of morphological pattern of anaemia in children: a hospital based study of 100 cases. International Journal of Scientific Research. 2018;7(10):67-68.

13. Rathna S, Venkatraman J, Govindaraj, Anand AS, Pavithran. Study of morphological pattern of anemia in children. $\mathbf{J}$ of Evolution of Med abd Dent Sci. 2014 July; 3(27):7540-43.

14. Stiller C, Golembiewski S, Golembiewski M, Mondal S, Biesalski H, Scherbaum V. Prevalence of Undernutrition and Anemia among Santal Adivasi Children, Birbhum District, West Bengal, India. International Journal of Environmental Research and Public Health. 2020;17(1):342.

15. Jain S, Chopra H, Garg SK, Bhatnagar M, Singh JV. Anemia in children: Early iron supplementation. Indian J Ped. 2000; 67(1): 19-21. 